\title{
Thomas Morrissey
}

Peter Kenney, SJ, 1779-1841: The Restoration of the Jesuits in Ireland, England, Sicily, and North America. Washington, DC: The Catholic University of America Press, 2014. Pp. xii + 529. Pb, \$39.95.

In 2014, to mark the two-hundredth anniversary of the restoration of the Society of Jesus by Pope Pius viI, Catholic University of America Press reissued Thomas Morrissey's biography of Peter Kenney, one of a handful of influential Jesuits who helped shape the Society's re-incarnation in the Englishspeaking world. Morrissey's original offering was available only in hardback. Its title-As One Sent: Peter Kenney, SJ, 1779-1841. His Mission in Ireland and North America (Dublin: Four Courts Press, 1996)—suggested that Kenney's activities in Ireland and the United States would be the book's only focus. The new title makes it clear that Kenney both influenced and was influenced by English and Italian as well as Irish and American Jesuits. The book itself makes it clear that no one is more familiar with the existing documents on Peter Kenney's life than Thomas Morrissey, whose research utilizes collections at more than a dozen different archives in three different countries.

Peter Kenney was born six years after Pope Clement XIV yielded to pressure from the monarchs of Spain, France, and Portugal, issuing a brief that formally suspended the operations of the Society of Jesus.Although Kenney was initially apprenticed by his family to a Dublin coachmaker, he attended evening classes at a school established by an ex-Jesuit specifically for poor apprentices and laborers. Kenney eventually abandoned his apprenticeship (or may have been dismissed from it) to study for the priesthood at St. Patrick's College in Carlow. He was part of a cohort of students whose tuition was paid for by ex-Jesuits living in Ireland. In exchange for this, the students agreed in writing to join the Society of Jesus when and if the order was ever re-established-a pledge that Morrissey calls "remarkable," given that the young men "had grown up in a world where Jesuits as a body were a thing of the past" and "hostility to the order had been fanned to a fierce blaze" (8-9).

Kenney was graduated from St. Patrick's in 1804 and soon entered the Jesuit novitiate at Stonyhurst College in England. Morrissey briefly alludes to the strange nature of the location, given that the Jesuits had "passed into legend in Britain as conniving men" (17). He notes that "for two centuries English Jesuits had found shelter from persecution in France and Flanders. Now they had been obliged to seek a haven in their homeland from persecution in Europe" (17) as revolutionary armies swept across the continent.

Morrissey clearly assumes (and perhaps not without reason) that his readers will be familiar enough with Jesuit history to know that Stonyhurst had originally been the College of St. Omers, a school for English Catholic boys set 
up by the Society in the Spanish Netherlands in the 1590s. The Society had established the school on the continent because England's penal laws outlawed Catholic education in that country; two hundred years later, the English Jesuits moved it first to Bruges, when the Society was expelled from France, and then to Liège, after the Society's suppression, and finally to England to escape the French armies. Readers who know all of this history will appreciate the irony; those who do not will not.

Indeed, although this book is rich with details about Peter Kenney's daily life (such as the fact that he found his stay at the Indian Queen Hotel in Washington, D.C. on the night of December 23, 1831, to be "unpleasant" [246]), Thomas Morrissey does not provide his readers with the kind of historical context that makes for a good read. Such context also helps to advance the argument that the things a particular person said or did were important and are something we should all know about.

We are, for instance, provided with no real discussion of the republican climate that Peter Kenney encountered when he visited the United States in the 1820 s and 1830 . Without that context, we cannot really understand why Kenney would have reported back to the general congregation of the Society of Jesus in Rome that "the American fathers were madly patriotic and freedom loving," and that because "religion had not captivated their hearts and minds, they resented being governed, or corrected, or instructed by foreigners" (141). We also cannot understand why Kenney's Jesuit colleagues in Maryland would have used the term "ignorant monarchists" (165) to describe priests in Europe who criticized them for owning slaves.

Still, there is something to be said for books and authors like this, which do the heavy lifting and make it possible for future scholars to utilize information that would otherwise be locked away in archives that are far apart, far away, and far from inexpensive to access. In this sense, Thomas Morrissey has done a great service in writing this book, particularly for scholars of American and Irish Catholic history, clerical orders (not just the Jesuits, but also the Irish Christian Brothers, the Irish Sisters of Charity, and the Irish Loreto Sisters, whom Kenney assisted), and Catholic education-in that Peter Kenney was involved with the founding and/or early administration of Clongowes Wood College in County Kildare, Ireland; Georgetown University in Washington, D.C.; and St. Louis University in Missouri.

\section{Maura Jane Farrelly}

Brandeis University

farrelly@brandeis.edu

DOI $10.1163 / 22141332-00301005-25$ 